\title{
SPINOSAD: CONTROL OF LEPIDOPTEROUS PESTS IN VEGETABLE BRASSICAS
}

\author{
B.M. HARRIS and B. MACLEAN \\ Research Division, Dow AgroSciences, New Zealand (Ltd.), \\ Private Bag, New Plymouth, New Zealand
}

\begin{abstract}
Four field trials were conducted in commercial cabbage and cauliflower crops in the Manawatu and Pukekohe, New Zealand. Four to six consecutive broadcast applications of the naturally occurring metabolite spinosad were made at 6-10 day intervals from 3-7 weeks post-transplanting to harvest. Spinosad gave a high level of control of diamondback moth (Plutella xylostella), white butterfly (Pieris rapae) and leaf miner (Scaptomyza sp.) larvae. Pest control and commercially acceptable brassica yield from spinosad was equivalent or superior to deltamethrin. Spinosad produced no visual signs of phytotoxicity.

Keywords: spinosad, vegetable brassicas, Plutella xylostella, Pieris rapae, Scaptomyza sp.
\end{abstract}

\section{INTRODUCTION}

Synthetic pyrethroid and organophosphate insecticides are used in New Zealand vegetable brassicas to control a range of lepidopterous pests. These pests include diamondback moth, DBM (Plutella xylostella) and white butterfly (Pieris rapae). There is increasing incidence of resistance to pyrethroid and organophosphate insecticides by diamondback moth (Bell and Fenemore 1990; Cameron et al. 1997) and a desire from within the industry to reduce chemical inputs. In addition, new products, with favourable safety and environment profiles, are sought to enable the introduction of integrated pest management programs.

Spinosad belongs to the spinosyn chemical class of insect control products. It is the naturally occurring metabolite (termed Naturalyte) derived from fermentation of the soil bacterium Saccharopolyspora spinosa. Spinosad is used for the control of insect pests on fruit and vegetable crops, cotton, tree and vine crops and ornamentals on a global basis. Targeted Lepidoptera include army worms (Spodoptera sp.), cutworms (Agrostis sp.), DBM, fruitworms (Heliothis sp.) and leafrollers (Tortricidae). Certain beetles and dipterous leafminers (Liriomyza sp. and Scaptomyza sp.), thrips and flies are also controlled (Anon. 1997). The efficacy of spinosad is at least equivalent to the synthetic pyrethroids, most organophosphate and carbamates and other synthetic insecticide chemistries (Bret et al. 1997). It is primarily effective through ingestion but does have contact activity. Spinosad acts quickly; the onset of insect control and protection of the plant occurs almost immediately and is irreversible. Symptoms of exposure are flaccid paralysis, cessation of feeding and motility, weak tremors and failure to recover. Immotile larvae are typically found immediately adjacent to a minute feeding hole and may take 4-5 days to disappear from leaves.

Spinosad affects a unique site on the nicotinic acetylcholine receptor on postsynaptic nerve cells. There is no cross resistance to, and its mode of action is different from, both synthetic and traditional biological insecticides (Salgado 1997). These features, in conjunction with the low toxicity of spinosad to most beneficial insects (Petersen et al. 1997), allows control of insecticide resistant pests and justifies its use as a foundation in insecticide resistance management programmes (Cameron et al. 1998). Spinosad has a reduced risk to humans compared to synthetic insecticides and an excellent environmental profile with reduced risk to fish, birds, earthworms and mammals (Saunders and Bret 1997).

Proc. 52nd N.Z. Plant Protection Conf. 1999: 65-69 


\section{MATERIALS AND METHODS}

During the summer of 1996/97, three trials were established in commercial cabbage crops in the Manawatu, and Pukekohe, New Zealand, with one further trial established in a commercial cauliflower crop in Pukekohe (Table 1). Prior to the first application, trials Pukekohe 1 and 2 and Manawatu 1 were not treated with insecticide, while Manawatu 2 was sprayed with insecticides by the grower.

Trials were of randomised complete block design with four replicates and an individual plot size of $12-15 \mathrm{~m}^{2}$. Each plot contained 3 rows of cabbages. Treatments were applied using compressed air small-plot sprayers, with hand held booms fitted with four hollow cone nozzles, at 38 or $50 \mathrm{~cm}$ centres, delivering 470 - 500 litres/ha at $300-400 \mathrm{kPa}$. Four to six consecutive applications of spinosad (6-96 g/ha - Success Naturalyte, Dow AgroSciences) and deltamethrin (10 g/ha - Decis Forte, BASF), at 6-10 day intervals, were made from 3-7 weeks post-transplanting until harvest. All treatments included a non-ionic wetting agent (Citowett, BASF). Fungicides appropriate for disease prevention were applied to all plots including untreated.

TABLE 1: Details of trials.

\begin{tabular}{|c|c|c|c|c|c|c|}
\hline $\begin{array}{l}\text { Trial } \\
\text { No. }\end{array}$ & Location & $\begin{array}{l}\text { Brassica } \\
\text { and } \\
\text { variety }\end{array}$ & $\begin{array}{l}\text { Transplant } \\
\text { date }\end{array}$ & $\begin{array}{l}\text { Application } \\
\text { date }\end{array}$ & $\begin{array}{l}\text { Spray } \\
\text { interval } \\
\text { (days) }\end{array}$ & $\begin{array}{l}\text { Harvest } \\
\text { date }\end{array}$ \\
\hline Puke 1 & Pukekohe & $\begin{array}{l}\text { Sovereign: } \\
\text { Cabbage }\end{array}$ & 10 Nov 96 & $\begin{array}{l}\text { 27 Dec } 96 \\
\text { 06 Jan } 97 \\
\text { 15 Jan } 97 \\
\text { 23 Jan } 97 \\
\text { 31 Jan } 97\end{array}$ & $\begin{array}{l}10 \\
9 \\
8 \\
8\end{array}$ & 07 Feb 97 \\
\hline Puke 2 & Pukekohe & $\begin{array}{l}\text { All year } \\
\text { Hybrid: } \\
\text { Cauliflower }\end{array}$ & 10 Nov 96 & $\begin{array}{l}\text { 27 Dec } 96 \\
\text { 06 Jan } 97 \\
\text { 14 Jan } 97 \\
\text { 23 Jan } 97 \\
\text { 30 Jan } 97\end{array}$ & $\begin{array}{l}10 \\
8 \\
9 \\
7\end{array}$ & 06 Feb 97 \\
\hline Man 1 & Manawatu & $\begin{array}{l}\text { Summer } \\
\text { globe: } \\
\text { Cabbage }\end{array}$ & 07 Jan 97 & $\begin{array}{l}30 \text { Jan } 97 \\
\text { 07 Feb } 97 \\
17 \text { Feb } 97 \\
\text { 26 Feb } 97 \\
\text { 08 Mar } 97 \\
14 \text { Mar } 97\end{array}$ & $\begin{array}{l}8 \\
10 \\
9 \\
10 \\
6\end{array}$ & 25 Mar 97 \\
\hline Man 2 & Manawatu & $\begin{array}{l}\text { Summer } \\
\text { globe: } \\
\text { Cabbage }\end{array}$ & 07 Jan 97 & $\begin{array}{l}\text { 17 Feb } 97 \\
\text { 26 Feb } 97 \\
\text { 08 Mar } 97 \\
14 \text { Mar } 97\end{array}$ & $\begin{array}{l}9 \\
10 \\
6\end{array}$ & 25 Mar 97 \\
\hline
\end{tabular}

Control of DBM, white butterfly and leaf miner (Scaptomyza sp.) was assessed by counting the number of larvae on 10-20 plants in the central row of each plot, 2-11 days after each application. White butterfly larval assessments were made in the Manawatu trials only. At harvest, 10 plants per plot were assessed for commercial acceptability (nil damage/infestation of cut and trimmed plants as submitted by grower, to the market for sale).

Data were analysed by 2 way ANOVA using LSDs to separate means. Means in the same column that are accompanied by the same letter are not significantly different at the $95 \%$ level of probability. 


\section{RESULTS AND DISCUSSION \\ Effect of spinosad on diamondback moth larvae}

Levels of DBM larvae varied throughout the season in all trials, but generally were not high (1.9-7.3 per 10 plants). Assessments from each trial which clearly demonstrated product efficacy, relative to untreated, are presented in Tables 2-3 below.

TABLE 2: Mean number of Diamond Back Moth larvae per 10 cabbages after broadcast applications of spinosad in the Manawatu and Pukekohe.

\begin{tabular}{|c|c|c|c|c|c|c|c|c|c|}
\hline \multirow[b]{2}{*}{ Treatment } & \multirow[b]{2}{*}{$\begin{array}{l}\text { Rate } \\
\text { (g ai/ha) }\end{array}$} & \multicolumn{4}{|c|}{ Manawatu 1} & \multirow{2}{*}{$\frac{\frac{\text { Man } 2}{10 \mathrm{Daa} 4}}{24 / 3 / 97}$} & \multicolumn{3}{|c|}{ Pukekohe 1} \\
\hline & & $\begin{array}{l}\text { Pre-trt } \\
29 / 1 / 97\end{array}$ & $\begin{array}{l}\text { 7Daa1 }{ }^{1} \\
6 / 2 / 97^{2}\end{array}$ & $\begin{array}{l}\text { 7Daa4 } \\
5 / 3 / 97\end{array}$ & $\begin{array}{l}\text { 11Daa6 } \\
\text { 25/3/97 }\end{array}$ & & $\begin{array}{c}\text { Pre-trt } \\
24 / 12 / 96\end{array}$ & $\begin{array}{l}5 \mathrm{Daa} 4 \\
28 / 1 / 97\end{array}$ & $\begin{array}{l}\text { 7Daa5 } \\
7 / 2 / 97\end{array}$ \\
\hline \multirow[t]{5}{*}{ Spinosad } & 6 & $2.7 \mathrm{a}$ & $0.3 b$ & $0.8 \mathrm{~b}$ & $1.0 \mathrm{~b}$ & $0.3 \mathrm{ab}$ & $2.1 \mathrm{a}$ & $1.3 b$ & $1.4 \mathrm{bc}$ \\
\hline & 12 & $1.3 \mathrm{a}$ & $0.3 b$ & $2.8 \mathrm{~b}$ & $0.6 b$ & $0.0 \mathrm{~b}$ & $2.0 \mathrm{a}$ & $1.0 \mathrm{bc}$ & $1.0 \mathrm{bc}$ \\
\hline & 24 & $2.8 \mathrm{a}$ & $0.0 \mathrm{~b}$ & $0.8 \mathrm{~b}$ & $0.6 b$ & $0.0 \mathrm{~b}$ & $2.3 \mathrm{a}$ & $1.0 \mathrm{bc}$ & $1.0 \mathrm{bc}$ \\
\hline & 48 & $2.9 \mathrm{a}$ & $0.0 \mathrm{~b}$ & $3.0 \mathrm{~b}$ & $0.0 \mathrm{~b}$ & $0.0 \mathrm{~b}$ & $1.8 \mathrm{a}$ & $0.3 \mathrm{c}$ & $0.5 \mathrm{c}$ \\
\hline & 96 & $3.2 \mathrm{a}$ & $0.0 \mathrm{~b}$ & $2.0 \mathrm{~b}$ & $0.0 \mathrm{~b}$ & $0.0 \mathrm{~b}$ & $2.3 \mathrm{a}$ & $0.5 b c$ & $0.8 \mathrm{c}$ \\
\hline Deltamethrin & 10 & $3.6 \mathrm{a}$ & $0.8 \mathrm{~b}$ & $0.5 b$ & $0.3 \mathrm{~b}$ & $0.3 \mathrm{ab}$ & $2.4 \mathrm{a}$ & $1.0 \mathrm{bc}$ & $2.0 \mathrm{~b}$ \\
\hline untreated & & $2.7 \mathrm{a}$ & $2.3 \mathrm{a}$ & $7.3 \mathrm{a}$ & $2.3 \mathrm{a}$ & $2.5 \mathrm{a}$ & $2.3 \mathrm{a}$ & $2.3 \mathrm{a}$ & $5.0 \mathrm{a}$ \\
\hline
\end{tabular}

${ }^{1}$ Daa $=$ days after application: 7Daa $1=7$ days after application 1 etc.

${ }^{2}$ Date of assessment.

TABLE 3: Mean number of Diamond Back Moth larvae per 10 cauliflowers after broadcast applications of spinosad in Pukekohe.

\begin{tabular}{lccccc}
\hline Treatment & $\begin{array}{c}\text { Rate } \\
\text { (g ai/ha) }\end{array}$ & $\begin{array}{c}\text { Pre-trt } \\
24 / 12 / 96\end{array}$ & $\begin{array}{c}\text { 3DAA1 } \\
30 / 12 / 96^{2}\end{array}$ & $\begin{array}{c}\text { 4DAA4 } \\
27 / 1 / 97\end{array}$ & $\begin{array}{c}7 \text { DAA5 } \\
6 / 2 / 97\end{array}$ \\
\hline Spinosad & 6 & $1.9 \mathrm{a}$ & $2.3 \mathrm{ab}$ & $1.8 \mathrm{~b}$ & $1.8 \mathrm{~b}$ \\
& 12 & $2.0 \mathrm{a}$ & $1.5 \mathrm{~b}$ & $1.3 \mathrm{bc}$ & $1.5 \mathrm{bc}$ \\
& 24 & $1.8 \mathrm{a}$ & $1.8 \mathrm{~b}$ & $1.0 \mathrm{bc}$ & $1.3 \mathrm{bc}$ \\
& 48 & $1.8 \mathrm{a}$ & $1.1 \mathrm{~b}$ & $0.5 \mathrm{c}$ & $0.5 \mathrm{c}$ \\
Deltamethrin & 96 & $2.0 \mathrm{a}$ & $1.3 \mathrm{~b}$ & $0.5 \mathrm{c}$ & $0.8 \mathrm{bc}$ \\
Untreated & 10 & $2.0 \mathrm{a}$ & $1.3 \mathrm{~b}$ & $0.5 \mathrm{c}$ & $1.8 \mathrm{~b}$ \\
& & $1.9 \mathrm{a}$ & $3.0 \mathrm{a}$ & $3.0 \mathrm{a}$ & $6.8 \mathrm{a}$ \\
\hline
\end{tabular}

${ }^{1} \mathrm{DAA}=$ days after application: 7DAA $1=7$ days after application 1 etc.

${ }^{2}$ Date of assessment.

Tables 2 and 3 show the populations of DBM larvae were uniform prior to the first application, and peaked in February in Pukekohe and March in the Manawatu. All treatments reduced the number of DBM larvae compared to untreated. Little or no dose response from increasing rates of spinosad was probably the result of relatively low pest populations (Dow AgroSciences, pers. comm.). Spinosad (12-96 g/ha) consistently gave control equivalent to deltamethrin $(10 \mathrm{~g} / \mathrm{ha})$.

Effect of spinosad on white butterfly larvae

White butterfly were not encountered in the Manawatu until March. Table 4 shows infestation levels were moderate at this time. All treatments reduced numbers relative to untreated. At 11DAA6 in trial Manawatu 1, a dose response from increasing rates of spinosad was visible. Spinosad (12-96 g/ha) gave control equivalent to deltamethrin (10 g/ha).

\section{Effect of spinosad on leaf miner larvae}

In the Manawatu trials, leaf miner larvae numbers were not high until the final assessment. Table 5 shows control of leaf miner larvae increased with the rate of spinosad. Spinosad (12-96 g/ha) reduced the number of leaf miner larvae compared to untreated and gave control equivalent to deltamethrin $(10 \mathrm{~g} / \mathrm{ha})$. 
TABLE 4: Mean number of white butterfly larvae per 10 cabbages after broadcast applications of spinosad in the Manawatu.

\begin{tabular}{lcccc}
\hline Treatment & Rate & \multicolumn{2}{c}{ Manawatu 1 } & Manawatu 2 \\
& 7DAA4 & 11DAA6 & 10DAA4 \\
(g ai/ha) & $5 / 3 / 97^{2}$ & $25 / 3 / 97$ & $0.5 \mathrm{~b}$ \\
\hline Spinosad & 6 & $0.0 \mathrm{~b}$ & $3.5 \mathrm{~b}$ & $0.0 \mathrm{~b}$ \\
& 12 & $0.0 \mathrm{~b}$ & $0.6 \mathrm{bc}$ & $0.8 \mathrm{~b}$ \\
& 24 & $0.0 \mathrm{~b}$ & $1.8 \mathrm{bc}$ & $0.3 \mathrm{~b}$ \\
& 48 & $0.0 \mathrm{~b}$ & $0.5 \mathrm{c}$ & $0.0 \mathrm{~b}$ \\
Deltamethrin & 96 & $0.0 \mathrm{~b}$ & $0.0 \mathrm{c}$ & $0.0 \mathrm{~b}$ \\
Untreated & 10 & $0.0 \mathrm{~b}$ & $0.8 \mathrm{c}$ & $19.0 \mathrm{a}$ \\
\hline
\end{tabular}

${ }^{1} \mathrm{DAA}=$ days after application: 7DAA $1=7$ days after application 1 etc.

${ }^{2}$ Date shown is date of assessment.

TABLE 5: Mean number of leaf miner larvae per 10 cabbages after broadcast applications of spinosad in the Manawatu.

\begin{tabular}{lccc}
\hline Treatment & $\begin{array}{c}\text { Rate } \\
\text { (g ai/ha) }\end{array}$ & $\begin{array}{c}\text { Manawatu 1 } \\
11 \text { DAA6 } \\
25 / 3 / 97^{2}\end{array}$ & $\begin{array}{c}\text { Manawatu 2 } \\
\text { 10DAA4 } \\
25 / 3 / 97\end{array}$ \\
\hline Spinosad & 6 & $2.8 \mathrm{bc}$ & $3.0 \mathrm{ab}$ \\
& 12 & $3.3 \mathrm{~b}$ & $1.5 \mathrm{bc}$ \\
& 24 & $2.5 \mathrm{bc}$ & $0.8 \mathrm{bc}$ \\
Deltamethrin & 98 & $0.3 \mathrm{c}$ & $0.3 \mathrm{c}$ \\
Untreated & 10 & $0.3 \mathrm{c}$ & $0.3 \mathrm{c}$ \\
& & $0.8 \mathrm{bc}$ & $0.8 \mathrm{bc}$ \\
\hline
\end{tabular}

${ }^{1} \mathrm{DAA}=$ days after application: 7DAA $1=7$ days after application 1 etc.

${ }^{2}$ Date shown is date of assessment.

TABLE 6: Percentage of commercially acceptable brassica heads ${ }^{1}$ at harvest following treatment of lepidopterous/leaf miner larvae with spinosad.

\begin{tabular}{lccccc}
\hline Treatment & $\begin{array}{c}\text { Rate } \\
\text { (g ai/ha) }\end{array}$ & Manawatu1 & Manawatu 2 & Pukekohe1 & Pukekohe 2 \\
\hline Spinosad & 6 & $93 \mathrm{ab}$ & $95 \mathrm{a}$ & $75 \mathrm{~b}$ & $88 \mathrm{~b}$ \\
& 12 & $100 \mathrm{a}$ & $100 \mathrm{a}$ & $82 \mathrm{bc}$ & $95 \mathrm{bc}$ \\
& 24 & $98 \mathrm{ab}$ & $100 \mathrm{a}$ & $96 \mathrm{c}$ & $97 \mathrm{bc}$ \\
& 48 & $100 \mathrm{a}$ & $100 \mathrm{a}$ & $96 \mathrm{c}$ & $100 \mathrm{c}$ \\
Deltamethrin & 96 & $100 \mathrm{a}$ & $98 \mathrm{a}$ & $97 \mathrm{c}$ & $100 \mathrm{c}$ \\
Untreated & 10 & $90 \mathrm{~b}$ & $98 \mathrm{a}$ & $73 \mathrm{~b}$ & $92 \mathrm{bc}$ \\
\hline
\end{tabular}

${ }^{1}$ Cabbage at Manawatu sites 1 and 2 and Pukekohe 1; Cauliflower heads at Pukekohe 2.

\section{Effect of spinosad treatments on head quality}

Table 6 shows percentage commercially acceptable brassica heads at harvest were low $(0-65 \%)$ in the untreated, despite low to moderate infestation pressures from DBM and white butterfly in both Pukekohe and the Manawatu. All rates of spinosad increased the yield of commercially acceptable brassica heads compared to untreated. In Pukekohe trials, a dose response from increasing rates of spinosad was visible. 
Spinosad (48 g/ha) gave a level of commercially acceptable brassica heads that was consistently equivalent to or greater than deltamethrin $(10 \mathrm{~g} / \mathrm{ha})$. This suggested DBM larvae present in these trials were less well controlled by, and may have been resistant to deltamethrin. However, this was not obvious from larval assessments. These results are very similar to percentage of commercially acceptable heads obtained in trials undertaken in the 1998/99 season (unpublished data, Dow AgroSciences).

\section{Crop injury}

Four to six consecutive applications of spinosad (6-96 g/ha) at 7-10 day intervals produced no visual signs of phytotoxicity to cabbages or cauliflowers in any trial.

\section{ACKNOWLEDGEMENTS}

The authors are grateful to those growers on whose properties the trials were conducted.

\section{REFERENCES}

Anon., 1997. Dow AgroSciences- Internal technical literature.

Bell, P.D. and Fenemore, P.G., 1990. Insecticide resistance in diamondback moth in New Zealand. Proc. $43^{\text {rd }}$ N.Z. Weed and Pest Control Conf:: 31-34.

Bret, B.L. et al., 1997. Biological properties of spinosad. Down to Earth 52:1: 6-13. Cameron, P.J. et al. 1997. Comparative insecticide resistance of New Zealand and North American populations of diamondback moth, Plutella xylostella (Lepidoptera: Plutellidae). N.Z. J. Crop Hort. Sci. 25: 117-122.

Cameron, P.J. and Chapman, R.B., 1998. Insecticide rotation strategy for managing insecticide resistance in diamondback moth (DBM). Report prepared for AGCARM and VegFed.

Dow AgroSciences. Personal communication with Dow AgroSciences personnel in Australia and USA.

Petersen, L.G. et al. 1997. Tracer Naturalyte Insect Control and IPM. Down to Earth 52(1): 28-34.

Salgado, V.L., 1997. The modes of action of spinosad and other insect control products. Down to Earth 52(1): 35-43.

Saunders, D.G. and Bret, B.L., 1997. Fate of spinosad in the environment. Down to Earth 52(1): 14-20. 